References:

1. Kunanbaeva S. S. (2014). Kompetentnostnoe modelirovanie profesionälnogo inoiazychnogo obrazovania. [Competent modeling of professional foreign language education.]- Almaty, s. 53

2. Milrud, R. P. (2004). Kompetentnöst v izuchenii iazyka // Inostrannyi iazyk v şkole.,[ Competence in the study of language // Foreign language at school.] - №7. - (s. 20-26)

3. Kunanbaeva S. S. (2014). Kompetentnostnoe modelirovanie profesionälnogo inoiazychnogo obrazovania [Competent modeling of professional foreign language education ] - s. 89-117.

4. Hutorskoi A. V. (2003). Klüchevye kompetensii kak komponent lichnostno orientirovannoi paradigmy obrazovania // Obşestvennoe obrazovanie. [Key Competencies as a Component of the Personally Oriented Education Paradigm // Public Education] № 2. (str. 54-61).

5. Lebedev O. E. (2004). Kompetentnostnyi podhod v obrazovanii // Şkölnye tehnologii.[Competence approach in education // School technology] - № 5.

МРНТИ 14.35.07.

https://doi.org/10.51889/2020-2.1728-7804.99

\author{
Ayazbayeva A., ${ }^{1}$ Aldaberdy A., ${ }^{2}$ Kabdenova A. ${ }^{3}$ \\ ${ }^{1,2,3}$ L.N.Gumilev Eurasian National University, \\ Nur-Sultan, Kazakhstan
}

\title{
EARLY LEARNING OF ENGLISH WITH FAIRY TALES, SONGS
}

\section{Abstract}

This article is about early education of English to children, with the help of fairy tales and songs. Fairy tale is best to the age children's characteristics of learning a foreign language, helps to develop their memory, thinking, attention and imagination. The article describes the experience and conclusions of various psychologists and teachers, examines the various positions of linguists. In this article various fairy tales and songs are offered, that are well received by children at an early stage. It is said, that this method is not fully studied, not enough evidence for making final or definite solution, but still there are good results in improvement of learning a foreign language.

Keyword: fairy tales, songs, lifelong education, the English language, early education, trilingualism

$$
\begin{gathered}
\text { Аязбаева Ә., }{ }^{1} \text { Алдабердіқызы А., }{ }^{2} \text { Кабденова А. }{ }^{3} \\
{ }_{1,2,3} \text { Л .Н.Гумилев атындавыЕуразия Ұлттық Университеті, } \\
\text { Нур-Султан, Казахстан }
\end{gathered}
$$

\section{КІШІ ЖАСТАҒЫ БАЛАЛРҒА АҒЫЛШЫН ТІЛІН ЕРТЕГІ МЕН ӘН АРҚЫЛЫ ҮЙРЕТУ}

\section{Аңุдатпа}

Бұл мақалада кіші жастағы балаларға ертегілердің көмегімен ағылшын тілін оқыту әдісі қарастырылады. Шет тілін оқыту кезінде ертегіні қолдану балалардың жас ерекшеліктеріне сәйкес келеді, ол баланың жадысын, ойлауын, назарын және қиялын дамытуға көмектеседі. Мақалада әр түрлі психолог-педагогтердің тәжірибесі мен қорытындылары ұсынылған, тіл .үйренушілердің түрлі ұстанымдары қарастырылған. Кіші жастағы балалар жақсы қабылдайтын әр түрлі ертегілер, әндер ұсынылған. Мақалада оқытудың бұл әдісі толық зерттелмеген, бірақ бала кезінен шет тілін үйренетін балалар арасында оң нәтижелер бар. Сондай-ақ, шет тіліндегі сөздер ертегі оку және ән үйрену арқылы ғана емес, сонымен қатар балалар түрлі-түсті жарнаманы, мультфильмдерді және т. б. көріп, естігенде есте қалуы мүмкін.

Түйін сөздер: ертегілер, әндер, шет тілі, үздіксіз білім беру, үштілдік, ерте оқыту 


\author{
Аязбаева А., ${ }^{1}$ Алдабердіқызы А., ${ }^{2}$ Кабденова А. ${ }^{3}$ \\ ${ }^{1,2,3}$ Евразийский Начиональный Университет имени Л.Н.Гумилева, \\ 2. Нур-Султан, Казахстан
}

\title{
ОБУЧЕНИЕ АНГЛИЙСКОМУ ЯЗЫКУ НА РАННЕМ ЭТАПЕ С ПОМОЩЬЮ СКАЗОК, ПЕСЕН
}

\begin{abstract}
Аннотащия
В данной статье рассматривается способ обучения английскому языку на раннем этапе с помощью сказок. Сказка лучше всего соответствует возрастным особенностям детей при обучении иностранному языку, помогает развивать память, мышление, внимание и фантазию ребенка. В статье предложены опыт и заключения различных психологов- педагогов, рассматриваются различные позиции языковедов. Предложены различные сказки, песни, которые хорошо воспринимаются детьми на раннем этапе обучения. В статье также акцентируется, что этот метод обучения не до конца изучен, но тем не менее имеются положительные результаты среди детей, изучающих иностранный язык с раннего детства. Также указывается, что слова на иностранном языке могут запоминаться не только при помощи чтения сказок и заучивания песен, но также когда дети видят и слышат красочную рекламу, мультфильмы и т.д.
\end{abstract}

Ключевые слова: раннее обучение, английский язык, непрерывное образование, трехъязычие

Introduction.Nowadays it is very common to educate our children a second language: French, English, Chinese, Spanish are at the top of the list. The better half of parents try to instill, promote love and cultivate language learning to their offspring from the beginning of their life, citing the fact that the little ones have a good memory, information is quickly absorbed, the brain is more plastic and captures messages at his first attempt, i.e. words in a foreign language are assimilated at a subconscious level, it becomes as, a parallel study, of both,our mother-tongue and second language. Currently, many experts relate to the issue of early education ambivalently. In the educational system of Kazakhstan, questions about pre-school education of FL are undergoing changes, as many experts believe that the introduction of English into the curriculum from the 1st grade affects successful learning of this subject in the next steps.

In the system of lifelong education, learning a foreign language in elementary school allows to effect the humanization and humanitarization of children's education, strengthening their developmental, educational, cultural and practical orientation. Moreover, system of education in Kazakhstan provides learning of three languages from the first grade.

It is known that primary school age is the most favorable for grasping the basics of a second language. Given the sensitive period for a child to perceive and reproduce speech, at an early age it is possible to develop and maintain the flexibility of the speech apparatus for the formation and improvement of a person's speech ability throughout his life[1].

Methods. All these changes, innovations in the methodology are aimed at the establishment of a trilingual education, the speech of which is supported by the First President of the Republic of Kazakhstan, and has been striving to introduce into schooling for many years. I.V. Rakhmanov wrotein 1947: "Most methods differ significantly from each other only at the elementary level of training." [2]. As in Russian (S. I. Rubinstein, L. S. Vygotsky, Yu. P. Azarov), and in foreign psychology (T. Eliot, J. Bruner, B. White), there are rules and regulations, and data that preschool and junior school child is much easier learns a foreign language.

Most scholars agree that it is the early period that is most successful for starting this process. However, as Maria Luz Zelaya, a researcher at the Early Learning Issues at the University of Barcelona, noted, the idea of "the sooner the better" is not always accurate. According to Maria Luz Zelaya, learning FL from 10-11 years old can be as effective as early learning (from 4-5 years old), since this process is supported by knowledge of the basics on the native language and personal, intellectual, emotional-volitional and physiological willingness of the child. Moreover, the process of learning FL from 4 years old can take more time and require more effort [3].

Another well-known scientist, Krashen, confirmed this hypothesis by examining the relationship between the three parameters of the study of FL: route, eventual result, and speed. The "route" describes the 
process of studying FL (order and sequence), and the "speed" describes the time interval during which the student will achieve the final result. According to his research, 11 years old students and older study FL faster and, accordingly, "go" faster. However, children who started studying FL from 4-5 years old, although they study it longer, but their result is better and more successful [3]. This is also explained by the skills acquired at the initial stage of automatic learning of language material and its repeated repetition in the process of learning FL.

Results.A baby, who is just starting to learn speaking, and preschool children (2-3 years old) do not see the border between different languages. They don't sense "transition" from one language to another. According to the experiment, children can combine several languages in one sentence. Especially in international families, where each parent speaks their own language with their child, and between themselves in English, or in Kazakhstan, where parents communicate in Kazakh, and outside the home, the child hears Russian-language speech, and in the learning center, where teaching is conductedin English, the child combines all the languages he knows in his speech. Forexample, - Мама, у нас же он алтыншыз этаж. Я хочу провести на Hallo ween horror challenge.That is, at an early age, the assimilation of information is fast. The child's memory rapidly develops and replenishes. At the junior preschool age, till 3-4 years old (more precisely, from two to five years), the child acquires a huge supply of words of everyday speech [4]. They already understand the content of simple fairy tales and poems and like to listen to them in the performance of adults. They easily remember small poems and fairy tales and reproduce them with great accuracy [5]. Accordingly, children can imitate foreign speech with the same ease if they are regularly allowed to watch cartoons in English, listen to audio recordings with fairy tales or facile poems.It is also should be emphasized, that children can easily remember words, slogans in foreign language by watching TV advertisements, they can reproduce these words every time when the hear song from ad.

Studying a foreign language in the early stages is a special area of the methodology of early learning of FL. The experiments that were carried out in various countries confirmed the idea that the inclusion of early learning of foreign languages in the system of continuing education only helps the harmonious development of the child's personality and develops both general and linguistic abilities. (Sh.A. Amonashvili, A.A. Leontiev, E.A. Negnevitskaya and others). Recently, researches have appeared, where the ways to integrate a foreign language and other subjects within the elementary school are noticed. Speaking of early learning a foreign language, not only practical, but also educational, developmental tasks should be solved. However, in the traditional methodology, issues related to the usage of retelling, interpretation of fairy tales in English and speaking learning on this basis were ignored.

Class of second language at an early age (be it English, French, Spanish) - is unknown, new experience for the child, which is a special atmosphere for his development. A child should have an idea ofa foreignspeaking culture first, and this, in turn, will help to activate the mechanisms of speech development and manure speaking and listening skills. Learning a second language is not only the process of improving or enlarging new vocabulary, it is also the expansion of world outlook. A fairy tale can serve as material for this activity, therefore, our research will examine in detail the question of teaching English speaking to younger students on the basis of fairy tales. The fairy tale is best suited to the age characteristics of children learning a foreign language, helps to develop the child's memory, thinking, attention and imagination. This side of fairy tale was mentioned by such scientists as L.S. Vygotsky, S. Buler, N.V. Karpinskaya.

Analysis of the methodological literature showed that the fairy tale is poorly understood method of teaching, practicing speaking a foreign language at an early stage. Having many advantages for early learning, a fairy tale is aninextricably structured genre of literary works. For example, the question of an adequate understanding of bedtime stories by primary school-aged children is still open. It is also important to note that, given all the positive aspects of using a tall story in early learning a foreign language, one may encounter the fact that the fairy tale or bedtime story is not often used in teaching younger students a foreign language.

Thus, the lack of a sufficient number of researches on this topic, as well as the appropriateness of the method of using fairy tales at the initial stage of teaching a foreign language, determine the topicality of our study.

An analysis was carried out, which revealed a number of fairy tales texts, which are most easily perceived by preschool children and with the help of which, children remember the main and basic speech units from these stories.

Fables, short stories, as well as speech units that children have learned by heart after reading this literature can be seen inTable 1 . 
Table 1

\begin{tabular}{|l|l|}
\hline Fairy tale & Speech unit \\
\hline Incredible Animals. & To hide, pollen, berries, arctic fox, tiger, baby, adult \\
\hline "Dad's Birthday and Other Stories" by Roderick Hunt & It's Mom. It's Dad. It's Biff. Biff did this. Oh no! \\
\hline "Dolphin Rescue" by Roderick Hunt & Go to sleep. I can't go to sleep. I know. It's boring. \\
\hline "What's the Weather Like Today?" by Clair Llewllyn. & $\begin{array}{l}\text { Sunny, windy, rainy, snowy, frosty, cloudy, a sunny day, } \\
\text { seaside, puddles, It's hot, snowballs, spider webs, }\end{array}$ \\
\hline "Stuck in the Mud" by Roderick Hunt & Go for a walk, muddy walk, what was that?, help me, etc \\
\hline "The Scarf" by Roderick Hunt & To like knitting, scarf, long and warm, what a cold day, \\
\hline "The Hedgehog" by Roderick Hunt & Hedgehog, dog, sharp, nose, stay \\
\hline
\end{tabular}

Reciting fairy tales with images to children at an early age, the words are assimilated at a subconscious and intuitive level, a process ofbuilding a language system takes place, similar to the procedure of speech acquisition by children. It should be noted, that it is better to read fairy tales first in native language, and then the same in English, in order to perceive the course content quicker and with interest by children. Offspring remember main heroes, their professions, their skills better, if they know meaning already first, for example, titles of animals, colors, geographical names. Famous excerpts from different fairy tales can be seen in Table 2 .

Table 2

\begin{tabular}{|l|l|}
\hline English variant & Russian variant \\
\hline - Cockerel, cockerel, & - Петушок, петушок, \\
Golden Scallop, & Золотой гребешок, \\
Oily head, & Масляна головушка, \\
Silk beard, & Шелкова бородушка, \\
Look out the window, & Выгляни в окошко, \\
I'll give you a pea. & Дам тебе горошку. \\
\hline - TeremTeremok! & - Терем-теремок! Кто в тереме живет? - Я, \\
Who lives in the tower? & мышка-норушка. - Я, лягушка-квакушка. - \\
"I, the mouse mouse." & Я, зайчик-побегайчик. - А ты кто? - А я \\
"I, the frog frog." & лисичка-сестричка. - Иди к нам жить! \\
"I, runaway bunny." - And who are you? & Забралась лисичка в теремок. Стали они \\
- And I'm a little fox sister. & вчетвером жить. \\
- Come live with us! The chanterelle climbed into the tower. & \\
The four of them began to live. & \\
\hline Open the door, my dear children, your mother is here, and has & Детки, милые, отомкнитесь, ваша мать \\
brought each of you something. & пришла, вам гостинцев принесла. \\
\hline
\end{tabular}

Conclusion. From the foregoing, it is believed that fairy tales as educational material when teaching 4-6 years old children unknowingly help the child remember unfamiliar words, while pictures help to understand the meaning.

Therefore, for a better result, learning a foreign language should be started from an early age ( $1^{\text {st }}$ group), even if the time spent on learning is the same as those who started learning English from a teenage age $\left(2^{\text {nd }}\right.$ group). In the process of learninga foreign language,children of the 1st group, their learning and perception is on automatic level and is remembered more smoothly compared to students of the $2^{\text {nd }}$ group.

In the future, it is planned to conduct more experimental research, based on cartoons, various anime for more successful results.

1 Сасенова У.К., ОмаровМ.К. УМКД по дисииплине “Английский язык”. URL:

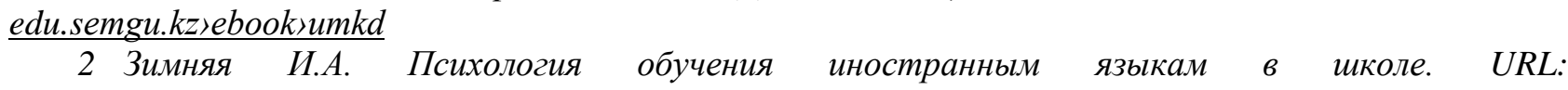
https://sheba.spb.ru/shkola/ocherk-inometod-1947.htm-Cmambя

3 Матвиенко Л.М. Раннее обучение детей иностранному языку: теория и практика //Научнометодический электронный журнал “Концепт". - 2018. -№6 (июнь).- C.347-356. - URL: https://cyberleninka.ru/article/n/rannee-obuchenie-detey-inostrannomu-yazyku-teoriya-i-praktika

4 Вейн А.М. Память человека. Журнал "Рsyera". - 2020.- URL: https://psyera.ru/5226/vozrast-ipamyat. - Статья 
5 Смирнова E.O. Психологическая характеристика раннего возраста. URL: http://childpsy.ru/rubricator/index.php?rid=20307\&detail=Y]. - Cтатья

$$
\text { References: }
$$

1. Sasenova U.K., OmarovM.K. UMKD po disipline "Angliski iazyk". URL: edu.semgu.kz>ebookıumkd

2. Zimnäia I.A. Psihologia obuchenia inostrannym iazykam $v$ şkole. URL: https://sheba.spb.ru/shkola/ocherk-inometod-1947.htm - Stätä

3. Matvienko L.M. Rannee obuchenie detei inostrannomu iazyku: teoria i praktika //Nauchnometodicheski elektronnyi jurnal "Konsept". - 2018. -№6 (iün).- S.347-356. - URL: https://cyberleninka.ru/article/n/rannee-obuchenie-detey-inostrannomu-yazyku-teoriya-i-praktika

4. Vein A.M. Pämät cheloveka. Jurnal "Psyera". - 2020.- URL: https://psyera.ru/5226/vozrast-ipamyat. - Stätä

5. Smirnova E.O. Psihologicheskaia harakteristika rannego vozrasta. URL: http://childpsy.ru/rubricator/index.php?rid=20307\&detail=Y ]. - Stätä 